\title{
Vertical Farming Using Hydroponic System: Toward a Sustainable Onion Production in Nueva Ecija, Philippines
}

\author{
Marilou P. Pascual'1, Gina A. Lorenzo², Arneil G. Gabriel ${ }^{3}$ \\ ${ }^{1}$ College of Management and Business Technology, Nueva Ecija University of Science and Technology, Cabanatuan, Philippines \\ ${ }^{2}$ College of Engineering, Nueva Ecija University of Science and Technology, Cabanatuan, Philippines \\ ${ }^{3}$ Department of Public Administration, Nueva Ecija University of Science and Technology, Cabanatuan, Philippines \\ Email: opats14@yahoo.com
}

How to cite this paper: Pascual, M.P., Lorenzo, G.A. and Gabriel, A.G. (2018) Vertical Farming Using Hydroponic System: Toward a Sustainable Onion Production in Nueva Ecija, Philippines. Open Journal of Ecology, 8, 25-41.

https://doi.org/10.4236/oje.2018.81003

Received: December 2, 2017

Accepted: January 8, 2018

Published: January 11, 2018

Copyright $\odot 2018$ by authors and Scientific Research Publishing Inc. This work is licensed under the Creative Commons Attribution International License (CC BY 4.0).

http://creativecommons.org/licenses/by/4.0/

\begin{abstract}
The development of new technology for food production is essential to sustain man's needs for survival. The use of farmlands for food production and industrial purposes goes beyond the carrying capacity of the environment. The study determined the applicability of Vertical Farming using Hydroponic Technology to onion production in Nueva Ecija, Philippines. The country is known as the onion capital of Southeast Asia. The study measured the technology's sustainability and acceptability to onion farmers. By using experimental method, interview, and Focused Group Discussions (FGD), the study established its viability. Three phases of field experiments were conducted in August 2016, May 2017 and July 2017 using the Vertical Farming and Hydroponics Technology and Single Factor Analysis of Variance. The results showed that there is significant difference in the growth of onion bulb per week and the suitability and comparability of the technology to conventional farming. The study concluded that the VFH technology is acceptable to most onion farmers except the aspect of the cost of initial investment which requires government subsidy for the ordinary onion grower to avail of this new and sustainable technology in onion production.
\end{abstract}

\section{Keywords}

Vertical Farming, Sustainability, Farm Management, Onion Production, Hydroponic, Ecosystem, Climate Change

\section{The Need for a Sustainable System of Food Production}

\subsection{Environment and Food Production}

Studies showed that by the year 2050, our growing global population would re- 
quire an estimate of 60 percent more food than we produce today [1] [2] [3]. This finding is correlated to the reality that the land resource where foods could be produced is finite. For instance, agricultural land covers only 38 percent while arable land covers 11 percent of the total land area. The data show that there will only be a measly 2 percent increase in agricultural land by the year 2040 [4]. Water is also a scarce resource [5]. Some watershed in the province is already in critical condition adversely affecting the quality of water used in agricultural productivity [6]. These situations affect the capacity of the earth to supply the demand for food. The presence of more than 3 billion people around the globe triggers high demand not only for food but also the land on which crops should grow. To meet the demands, modern agriculture employs a variety of chemical products and exposure to toxic levels of some classes of agrochemicals. For instance, pesticides high in chemical contents are developed to combat insects that are continuously getting immune to low synthetic pesticides contents. Incidentally, the situation poses a greater danger to human beings because it is estimated that only 5 percent of all pesticides sprayed hit its intended weed and pest targets [7]. The rest is either absorbed into the ground, into the water, or into the food we eat [8].

\subsection{Food Production and Land Use in the Philippines}

The demand for food production in the Philippines puts stress on land use and natural resources. The forestland alone is extremely suffering from degradation. The latest record from government agency shows that there is an estimate of 6.8 hectares of forestlands with a net loss of 400,000 hectares every year. The cause of this destruction is attributed to food production [9]. Therefore, to maintain sustainable food production while providing housing and industrial uses to lands [10], House Bill 4750 or the "Urban Agriculture Act of 2011", and House Bill No. 720 known as the "Urban Agriculture Act of 2013", mandate the Department of Agriculture and Department of Science and Technology, to promote the use of urban agriculture and vertical farming. These two laws aim to ensure food security and rejuvenate the ecosystem functions. The law further mandates that abandoned government lots and buildings owned by the national or local governments or available land resources of state universities and colleges shall be considered for growing crops, raising lives tocks purposely to sustain the demand for food production using vertical farming and urban gardening. Furthermore, the methods would be included in the academic curricula in secondary and tertiary levels of education both in the private and public schools [11].

\subsection{The Onion Production in Nueva Ecija}

The Philippines is an agricultural country with a land area of 30 million hectares. 47 per cent of which is agricultural land. Of the total area used for food crops, Two Hundred Seventy Thousand hectares are used to grow vegetables and root crops. Among them is Bulb onion (Allium cepa L.). It is a favorite culinary in- 
gredient in the Philippines and in Southeast Asia. There are about 12,000 hectares of farm lands planted with onion in Nueva Ecija and Ilocos region. The province of Nueva Ecija is the leading producer of onion accounting for 99 percent of the region's onion production. The weather condition in the province experiences two seasons a year. The dry season during the months of November to April while the wet season occurs during the rest of the months of the year. Among the municipalities in Nueva Ecija, Bongabon is known as the onion capital of the Philippines because of the volume it produced [12]. In this study, shallot (Sibuyas Taga log/Tanduyong) variety of onion is used because it can be grown almost throughout the year.

At present, onion production in Nueva Ecija is threatened by importation, smuggling, and the emergence of pests bringing havoc to potential earnings of onion farmers. There are about 3000 hectares of onion plants affected by "armyworms" resulting in the dramatic decline in the production of this crop in the region. There are three reasons cited for the decrease in onion production in Nueva Ecija: 1) The prolonged rainy season; 2) Farmers losing their market share because of the coming in of imported onion; 3) Emergence of insects causing the drop in harvest.

At this juncture, the literature shows that development of the onion industry in the Philippines is facing a challenge. The declining production of the industry demands that new model and a new system of farming needs to be reconsidered. Despite the present state of the industry, there is no sufficient number of researchers applying new technology and method of making onion production viable. A necessary means to maintain its mark as the onion capital of Southeast Asia. Therefore, the present study aims at using the technology of vertical farming and hydroponics as a viable system of producing onion. Investigate on the possibility of adopting vertical farming technology which might serve as a potential solution to the problems facing onion production in Nueva Ecija.

In view of the above discussion, the study posed the following statements of the problem: 1) How may the need for a sustainable system of production of onion be described in terms of viability; 2) What is vertical farming using hydroponics; 3) How may vertical farming using hydroponic system be described in terms of, production cost; usability for onion production; manageability of farm activities and acceptability to farmers and onion growers? 4) How may the vertical farming using hydroponics be described in Nueva Ecija; 5) How may the findings of the study contribute to agricultural productivity in the onion industry in Nueva Ecija?

\section{Vertical Farming Using Hydroponic System}

\subsection{Vertical Farming}

Vertical farming (VF) or high-rise farming is a proposed indoor, urban farming technology involving large-scale agricultural production in multi-story buildings

[13]. While, hydroponics and aeroponics methods are tools to produce crops in 
soil-less nutrient solutions.

Vertical Farming promises to eliminate external natural processes since crops will be grown under carefully selected and well-monitored conditions, ensuring an optimal growth rate for each species of plant and animal year-round [14]. It eliminates the need for fossil fuels to run machinery during the different stages of farming (i.e., plowing, applying fertilizer, seeding, weeding, harvesting) [15]. It is estimated that one acre of vertical farming is equivalent to ten to twenty soil based farmlands [16].

Vertical Farming has the following advantages compared to traditional farming practices: 1) Year-round crop production as it requires no soil rejuvenation and soil mineral recovery ordinarily observed in land-based farming. 2) Significantly reduces farm inputs and the use of fossil fuels causing damage to the environment. Land-based agriculture requires land plowing using farm implements burning gasoline and other petroleum products. 3) The technology can be put up anywhere; 4) it minimizes weather and crop failures as it is under a controlled environment the farmer himself sets; 5) it helps in restoring the farmland to the ecosystem.

\subsection{The Hydroponic System}

Hydroponics is one of the many methods of soilless agriculture through which plants are grown in mineral nutrient water [17]. The mineral nutrient can be introduced into a plant's water supply which is then readily absorbed by the plant's root. Many vegetables are grown using hydroponics. The principle behind its operation is that, the land is a mere storage of nutrients needed by plants to grow. Thus, if the same nutrients are to be provided using treated water, the same result may be had.

The hydroponic technology allows small farmers to grow food even in dry spells. The prolonged dry season, caused by El Nino phenomenon, will not affect the onion production. According to one expert, "If the time comes when there's severe water shortage, at least we have a system where we can plant and grow crops with little water," [18]. However, critics of the method in developing countries considered the significant amount needed to implement the technology. The startup costs to implement a hydroponic farm can vary widely but, they are usually much more significant than soil-based farming [19]. The initial capital required, is seen as a factor that will slow the adoption of the technology [20].

\subsection{Vertical Farming Using Hydroponics System}

The Proposed Design of a Hydroponic Vertical Grower is shown in Figure 1.

The vertical hydroponic grower is a 9-m, diamond-shaped structure consisting of 30 tiers of troughs made up of 7.6-cm-diameter, 2.5-m-long PVC pipes. The gutters are connected to a chain-sprocket system so that it will rotate around the A-frame for the checking and caring for the plants and harvesting the crops. Water is supplied at the upper-middle trough from an overhead tank, 


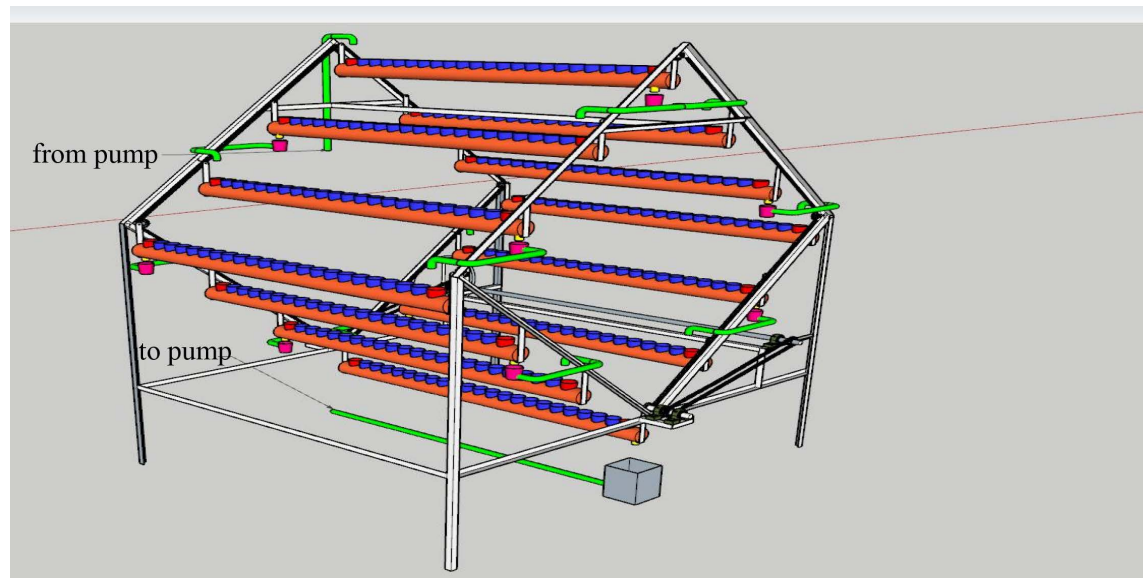

Figure 1. Proposed design of a hydroponic vertical grower.

$9.2 \mathrm{~m}$ high and circulated through each pipe and then drains at the lower-middle channel. Drain water will be recalculated again by a pump. During checking and harvesting periods, the valve connecting to the main water supply will be shut down and will be opened again once the plants were checked for any waterborne disease or cutting of rotten leaves. The same method will also be used during harvesting. The pipe that connects each trough is a flexible hose so that it will conform to the A-shape of the frame as the troughs rotate. Each trough will contain 25 onion bulbs spaced at $10 \mathrm{~cm}$ apart. The vertical hydroponic grower can grow 750 bulbs of the onion of onion per rack (the A-shaped structure). The frame has a foot area of $2.5 \mathrm{~m} \times 2 \mathrm{~m}\left(5 \mathrm{~m}^{2}\right)$. A $1500 \mathrm{~m}^{2}$ lot area could contain 200 racks and would produce $15,000 \mathrm{~kg}$ of onion almost equivalent to 1 hectare of traditional farming unaffected by any adverse weather and growing conditions.

\section{Methodology}

The study employed the experimental method of research. The dependent variable will be the onions that will be grown in the hydroponic vertical grower which is considered as the independent variable. The vertical hydroponic grower will control the growth of the onions. Other methods of gathering data were also used, such as library research, literature review, interview and personal observation. The use of interview was devoted to determining the acceptability of vertical farming to Onion farmers and growers. The literature review was used to determine the current agricultural practices and compare it with the hydroponic method. Meanwhile, interview with onion farmers to estimate the cost of onion production using traditional method was set. The experimental method was used to determine the suitability of vertical farming using the hydroponic system to onion production. The sampling method used was convenience sampling and purposive sampling observing the following criteria: 1) must be a farmer or grower of onion; 2) must be doing the planting for more than five years; 3 ) willing to be interviewed; 4) a resident of Bongabon Nueva Ecija. The respondents were identified on actual farm environment. The researchers went to the farm and interviewed onion planters /farmers. Some did not cooperate because they are al- 
ready satisfied with the yield produced by using traditional method or landbased onion production. Focus Group Discussion was also held to reinforce the results and findings using other tools to gather data.

The weather condition affects the plant growth. As shown in Figure 2, the hottest temperature in the month of August 2016 when the first phase of experiment was done is $37^{\circ} \mathrm{C}-38^{\circ} \mathrm{C}$. The weather conditions during the three-phase experiment are presented below. Figure 3 shows the highest actual dry temperature of 38 degrees celsius in the month of May 2017 when the experiment was undertaken. Figure 4 shows the weather temperature of around 34 degrees Celsius when the last phase of the experiment was held in July 2017. Based on the temperature graph shown, the hottest temperature was in the month of August 2016 is $37^{\circ} \mathrm{C}-38^{\circ} \mathrm{C}$. Both the hydroponically and soil grown onions were exposed to sunlight from 7 am to $11 \mathrm{am}$ and then kept under the shed from $11 \mathrm{am}$ onwards. Since August is a rainy season in the study area, the volume of rains may contaminate the chemically treated water in the hydroponic technology. Thus, the researchers made it sure that the samples are kept in a shed otherwise rain water would mix up with the nutrients in the water and may affect the growth of the onion.

The rainy season officially starts in the month of May. The experiment was

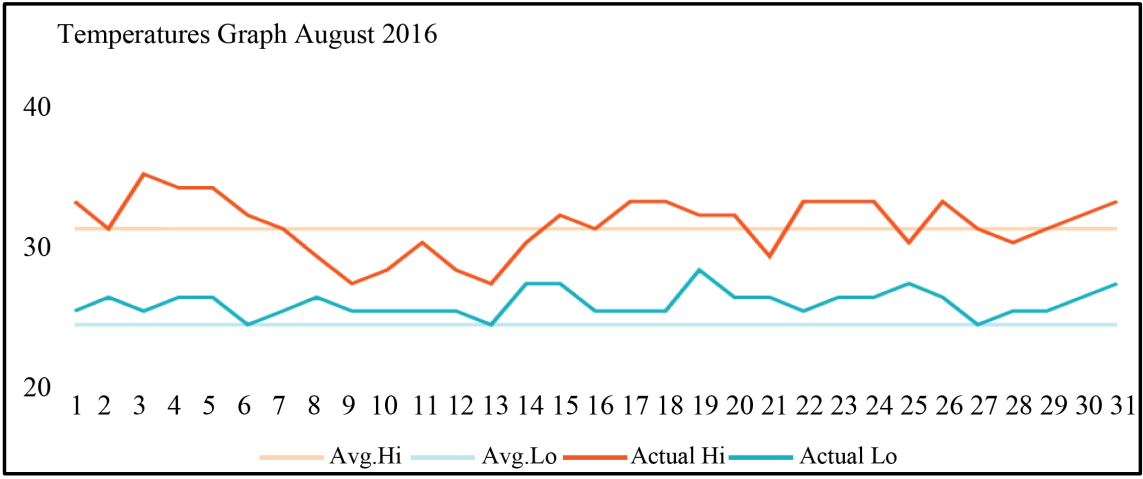

Figure 2. Weather temperatures in August 2016 Source: http://www.accuweather.com/en/ph/philippines-weather.

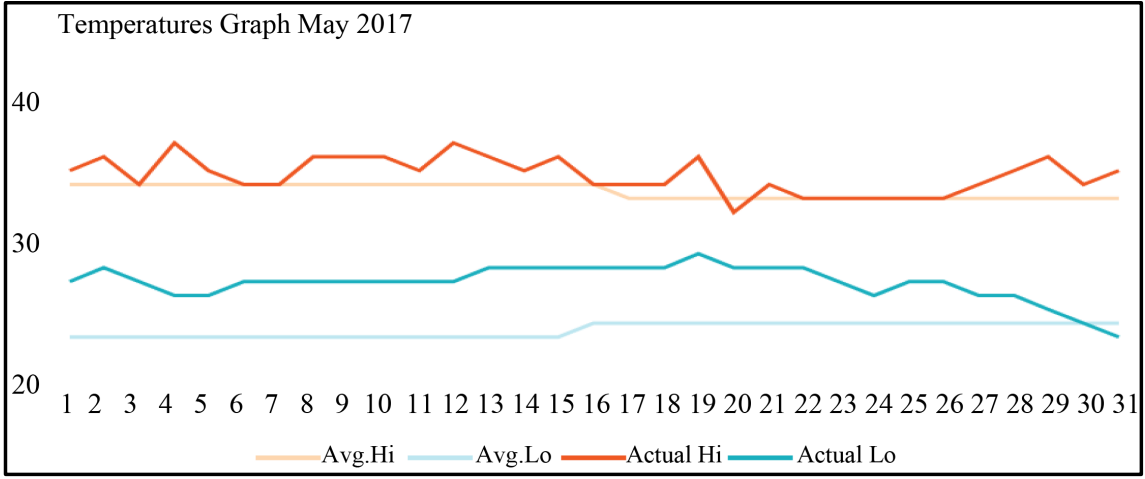

Figure 3. Weather temperatures in May 2017 Source: http://www.accuweather.com/en/ph/philippines-weather. 


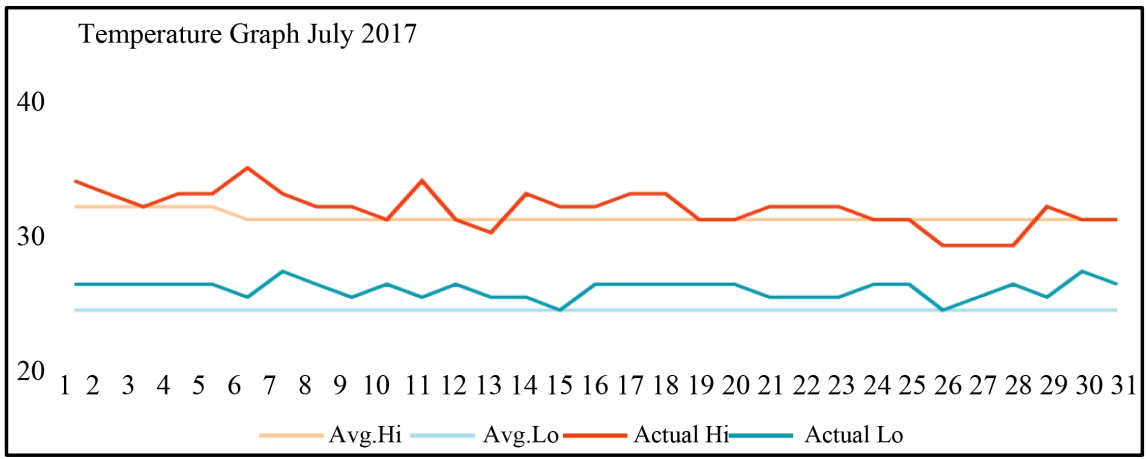

Figure 4. Weather temperatures in July 2017 Source:

http://www.accuweather.com/en/ph/philippines-weather.

performed mainly under the shed where it may be exposed to indirect sunlight in the morning.

\section{Description of Vertical Farming Using Hydroponics as a Sustainable Agricultural System}

\subsection{Cost of VFH}

Vertical hydroponic farm facilities require more capital than traditional farming. Numerous overhead costs (fixed and variable) like the construction of the greenhouse, a viable model or tray systems or buckets to name a few. These may be a disadvantage; however, the literature shows that the larger-scale hydroponic systems tend to be more cost-effective than small-scale land-based farms. The cost analysis of using the hydroponic grower as compared to traditional farming is shown in Table 1. As it is presented, the payback period starts in the third year. On the other hand, the traditional method allows the payback period within one year. The harvest under a traditional method may be affected by weather condition and other causes extraneous to the traditional farmer. Table 1 shows the cost analysis of vertical farming using hydroponics and its comparison to traditional land-based farms.

As presented in Table 1, on the second year, the total remaining balance in Vertical Hydroponic Farming (VHF) method will be \$59954.94. The remaining loan balance is $\$ 48,000$ which could be paid in full. And the remaining balance will be $\$ 11954.94$ less the total operational expenditure of $\$ 8010.47$. On the third year, the initial investment will be $\$ 3944.47$. Therefore, the Return On Investment (ROI) will be in the second year. Moreover, the remaining area of land $\left(7500 \mathrm{~m}^{2}\right)$ could be utilized for planting other crops. For the traditional farming method, although the loan was paid immediately, it is shown that the remaining balance on the second cropping is smaller than that of the VHF method. However, in the traditional method, third cropping is not possible because the land must recoup from the exhaustion of nutrients due to the two cropping seasons and the weather condition during the third cropping is volatile and inappropriate for onion production. More so, using the traditional method, the entire $10,000 \mathrm{~m}^{2}$ farmland area was used while in VHF system, the remaining lot space 
Table 1. Table of comparative cost analysis per hectare of onion using hydroponic method and traditional method.

\begin{tabular}{|c|c|c|}
\hline Items & $\begin{array}{c}\text { Vertical Hydroponic } \\
\text { Farming ( } 2500 \mathrm{~m}^{2} \text { land area) } \\
\text { Useful life of item 1:20 years } \\
\text { Loan: } \$ 60,000\end{array}$ & $\begin{array}{c}\text { Traditional Farming } \\
\left(10,000 \mathrm{~m}^{2} \text { land area }\right) \\
\text { Useful life of item 1:2 year } \\
\text { Loan: } \$ 10,000\end{array}$ \\
\hline \multicolumn{3}{|l|}{ Year $1,1^{\text {st }}$ Cropping } \\
\hline 1. Initial Cost (Equipment and Accessories) & $\$ 44,151.77$ & $\$ 488.44$ \\
\hline \multicolumn{3}{|l|}{ 1. Operational Expenditures } \\
\hline Seedling Preparation & $\$ 876.90$ & $\$ 413.90$ \\
\hline Variable Cost & $\$ 333.57$ & $\$ 1540.56$ \\
\hline Loan (fixed interest @ 24\% per annum) & $\$ 4800$ & $\$ 1200$ \\
\hline Loan Capital Deducted & $\$ 2000$ & $\$ 1000$ \\
\hline 2. Total Operational Expenditures & $\$ 8010.47$ & $\$ 4154.46$ \\
\hline 3. Total Expenditures & $\$ 52162.24$ & $\$ 4642.90$ \\
\hline $\begin{array}{l}\text { 4. Projected Yield per hectare/cropping: } \\
8 \text { tin cans } \times 1.5 \mathrm{MT} / \mathrm{can}=12,000 \mathrm{~kg} \times \$ 1.39 / \mathrm{kg}\end{array}$ & $\$ 16,680$ & $\$ 16,680$ \\
\hline 5. Projected income per cropping (Projected yield-operational expenditures) & $\$ 8669.53$ & $\$ 12,037.10$ \\
\hline $\begin{array}{l}\text { 6. Remaining Balance (considering a loan payable in } 10 \text { years with } 24 \% \\
\text { interest per annum: (loaned amount-item } 3 \text { ) }\end{array}$ & $\$ 7837.76$ & $\$ 5357.10$ \\
\hline 7. Total Remaining Balance: $(5+6)$ & $\$ 16,607.29$ & $\$ 17,394.20$ \\
\hline Year $1,2^{\text {nd }}$ Cropping & & Loan fully paid \\
\hline 1. Initial Investment & $\$ 16,607.29$ & $\$ 8394.20$ \\
\hline 2. Total Operational Expenditures & $\$ 8010.47$ & $\$ 1954.46$ \\
\hline $\begin{array}{l}\text { 3. Projected Yield per hectare/cropping: } \\
8 \text { tin cans } \times 1.5 \mathrm{MT} / \mathrm{can}=12,000 \mathrm{~kg} \times \$ 1.39 / \mathrm{kg}\end{array}$ & $\$ 16,680$ & $\$ 16,680$ \\
\hline $\begin{array}{l}\text { 4. Projected income per cropping } \\
\text { (Projected yield-operational expenditures) }\end{array}$ & $\$ 8669.53$ & $\$ 14,725.54$ \\
\hline 5. Remaining Balance: $(1+4)$ & $\$ 25,276.82$ & $\$ 23,119.74$ \\
\hline \multicolumn{3}{|l|}{ Year $1,3^{\text {rd }}$ Cropping } \\
\hline 1. Initial Investment & $\$ 25,276.82$ & \\
\hline 2. Total Operational Expenditures & $\$ 8010.47$ & \\
\hline $\begin{array}{l}\text { 3. Projected Yield per hectare/cropping: } \\
8 \text { tin cans } \times 1.5 \mathrm{MT} / \mathrm{can}=12,000 \mathrm{~kg} \times \$ 1.39 / \mathrm{kg}\end{array}$ & $\$ 16,680$ & \\
\hline 4. Projected income per cropping (Projected yield-operational expenditures) & $\$ 8669.53$ & \\
\hline 5. Remaining Balance: $(1+4)$ & $\$ 33,946.35$ & \\
\hline
\end{tabular}

could be used for other agricultural and live stocks production. The VHF is also free from unfavorable weather condition as the onion grows under an artificial environment and controlled physical surroundings.

\subsection{Usability of VFH to Onion Production}

In many studies, the plant's growth rate is higher in Vertical farming using hydroponics technology. Using the system will provide the farmer control of the farm allowing more significant results. With hydroponics, the farmer will have 
full control over the farm together with more optimal results. The growth of onion is shown in Tables 2-4 below. Hydroponic onion did as well if not even better than the plants grown in soil. Notwithstanding the higher cost of initial

Table 2. Phase 1: Experiment conducted in August 2016 Hydroponic Onion Data (30 days).

\begin{tabular}{cccc}
\hline Days & $\begin{array}{c}\text { Average Diameter of Onion } \\
\text { Bulb (cm) }\end{array}$ & Days & $\begin{array}{c}\text { Average Diameter of } \\
\text { Onion Bulb }(\mathrm{cm})\end{array}$ \\
\hline $\mathbf{1}$ & 2.0 & 16 & 2.3 \\
$\mathbf{2}$ & 2.0 & 17 & 2.3 \\
$\mathbf{3}$ & 2.0 & 18 & 2.4 \\
$\mathbf{4}$ & 2.1 & 19 & 2.4 \\
$\mathbf{5}$ & 2.1 & 20 & 2.5 \\
$\mathbf{6}$ & 2.1 & 21 & 2.5 \\
$\mathbf{7}$ & 2.1 & 22 & 2.5 \\
$\mathbf{8}$ & 2.1 & 23 & 2.5 \\
$\mathbf{9}$ & 2.1 & 24 & 2.7 \\
$\mathbf{1 0}$ & 2.1 & 25 & 2.8 \\
11 & 2.2 & 26 & 3.0 \\
$\mathbf{1 2}$ & 2.2 & 27 & 3.0 \\
$\mathbf{1 3}$ & 2.2 & 28 & 3.1 \\
$\mathbf{1 4}$ & 2.3 & 29 & 3.1 \\
$\mathbf{1 5}$ & 2.3 & 30 & 3.1 \\
\hline
\end{tabular}

Initial bulb diameter: $2 \mathrm{~cm}$.

Table 3. Phase 2: Experiment conducted in May 2017.

\begin{tabular}{cccc}
\hline Days & $\begin{array}{c}\text { Average Diameter of } \\
\text { Onion Bulb (cm) }\end{array}$ & Days & $\begin{array}{c}\text { Average Diameter of } \\
\text { Onion Bulb }(\mathrm{cm})\end{array}$ \\
\hline $\mathbf{1}$ & 2.0 & 16 & 2.6 \\
$\mathbf{2}$ & 2.0 & 17 & 2.9 \\
$\mathbf{4}$ & 2.1 & 18 & 3.0 \\
$\mathbf{5}$ & 2.1 & 19 & 3.0 \\
$\mathbf{6}$ & 2.2 & 20 & 3.1 \\
$\mathbf{7}$ & 2.2 & 21 & 3.2 \\
$\mathbf{8}$ & 2.3 & 22 & 3.3 \\
$\mathbf{9}$ & 2.3 & 23 & 3.5 \\
10 & 2.4 & 24 & 3.8 \\
11 & 2.4 & 25 & 3.9 \\
12 & 2.4 & 26 & 4.0 \\
13 & 2.5 & 27 & 4.1 \\
$\mathbf{1 4}$ & 2.3 & 28 & 4.1 \\
$\mathbf{1 5}$ & 2.4 & 29 & 4.1 \\
\hline & 2.5 & 30 & 4.1 \\
\hline
\end{tabular}


Table 4. Phase 3: Experiment conducted in July 2017.

\begin{tabular}{cccc}
\hline Days & $\begin{array}{c}\text { Average Diameter of } \\
\text { Onion Bulb (cm) }\end{array}$ & Days & $\begin{array}{c}\text { Average Diameter of Onion } \\
\text { Bulb (cm) }\end{array}$ \\
\hline $\mathbf{1}$ & 2.0 & 16 & 2.8 \\
$\mathbf{2}$ & 2.0 & 17 & 2.9 \\
$\mathbf{3}$ & 2.1 & 18 & 2.9 \\
$\mathbf{4}$ & 2.1 & 19 & 3.0 \\
$\mathbf{5}$ & 2.2 & 20 & 3.1 \\
$\mathbf{6}$ & 2.2 & 21 & 3.2 \\
$\mathbf{7}$ & 2.3 & 22 & 3.2 \\
$\mathbf{8}$ & 2.4 & 23 & 3.3 \\
$\mathbf{9}$ & 2.5 & 24 & 3.5 \\
10 & 2.5 & 25 & 3.6 \\
11 & 2.6 & 26 & 3.8 \\
12 & 2.6 & 27 & 4.1 \\
13 & 2.7 & 28 & 4.1 \\
14 & 2.7 & 29 & 4.2 \\
15 & 2.8 & 30 & 4.3 \\
\hline
\end{tabular}

capital, increase crop yields would compensate the investment [20]. The system can also serve as an alternative to land-based farming in areas where the land soil is poor in quality. When the technology is applied correctly, the growth of the plants is observable hence could provide earlier harvest resulting in three cropping seasons per year. Table 2 shows the data yielded by the experiments.

The Table 2 presents the growth of onion planted in a vertical grower applying the hydroponic system of providing nutrients to the onion. It is observed that there is a $2.5 \mathrm{~cm}$ average bulb diameter yielded within a 30 day period. From the $2 \mathrm{~cm}$ initial bulb development, it grew to 3.1 on the 30th day of the experiment.

On the next scheduled experiment in May 2017, the initial bulb diameter on the first day developed to $4.1 \mathrm{~cm}$ on the 30th experimental day. This goes to show that compared to the first experimental phase the bulb development of onion in the second experiment is relatively bigger. The result is attributed to extraneous variables which the researchers were not able to control in the first phase of the experiment. On the average, the onion bulb development in the second experiment yielded an average growth of $3 \mathrm{~cm}$ in a 30-day period.

The results of the final and last phase of the experiment are shown in Table 4. As it is depicted in the table. There was a $0.02 \mathrm{~cm}$ increased in the development of bulb diameter compared to Table 3 Phase 2 experiment yielding only a $4.1 \mathrm{~cm}$ growth of onion bulb smaller than the result of July 2017 3rd and last phase of the experiment.

The three phases of laboratory experiments scheduled in three different crop 
seasons clearly showed that the technology is adaptable to onion growing. The results of the experiments are similar to that found out by the researchers of the National Aeronautics and Space Administration (NASA). The present study affirms the result of the NASA researches where onion, like any other vegetables, can be grown using artificial simulated environment. The Figure 5 shows the actual observation of the study.

The Figure 5 showed the hydroponic technology as applied by the scientists having the vision to bring the technology in outer space where there is no land or soil where plant or vegetables could be transplanted to sustain their food. [21]. The NASA researchers are checking hydroponic onions with Bibb lettuce to his left and radishes to the right. Hydroponics technology provides the nutrients that land-based farming does. Whether it is in water or on land, the same nutrients for plant growth are essential. After all, plants rely on specific nutrients to grow, and these nutrients don't change, no matter which system one is using.

\subsection{Statistical Analysis of Bulb Growth Using VHF Technology}

In this experiment, the researcher used an 8-week old seedling called "setts" from the nursery bed. The setts were transplanted in the hydroponic grower and on soil. 18 bulbs were observed in each method. Average bulb diameter was measured daily. Using Single Factor ANOVA to test the difference in growth of onions, the data for each phase were grouped per week and the summary of computations are shown in Tables 5-7.

All three tables show the following results:

1) For F-test, $F>F_{\text {crit }}$, hence there is a significant difference in onion growth per week.

2) For P-test, $P<0.05$ also indicates the significant difference in onion growth per week.

Using the single factor ANOVA, the results show that there is enough evidence to prove that there is significant difference in the growth of onion bulb

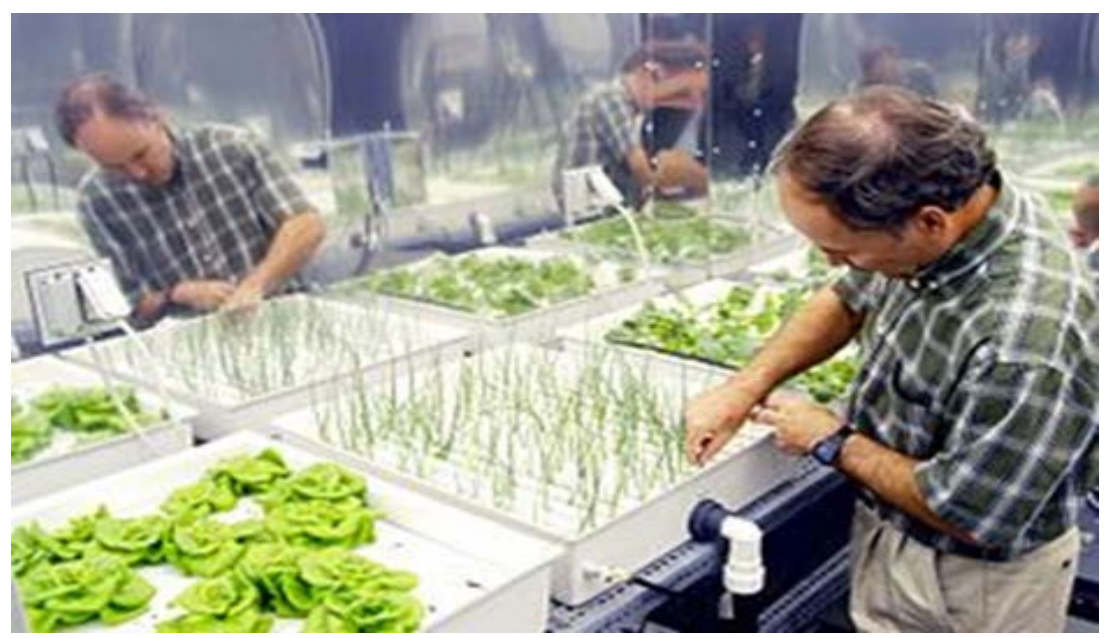

Figure 5. Hydroponic technology.

https://www.nasa.gov.centers/kennedy/home//index.html 
when measured per centi meter per week for within the period of one month. The $\mathrm{P}$ Value and $\mathrm{F}$ test results are presented below:

PHASE 1: Hydroponic Onion Data (August, 2016)

Week 1:

\begin{tabular}{ccccccc}
\hline ANOVA & \multicolumn{7}{c}{ MS } & $F$ & P-value & Fcrit \\
\hline Source of Variation & $S S$ & $d f$ & 6.082381 & 9.4922 & $1.64 \mathrm{E}-08$ & 2.175659 \\
Between Groups & 0.494286 & 6 & 0.059 & & \\
Within Groups & 1.032778 & 119 & 0.008679 & & & \\
Total & 1.527063 & 125 & & & & \\
\hline
\end{tabular}

Week 2:

\begin{tabular}{ccccccc}
\hline ANOVA & \multicolumn{7}{c}{ SS } & $d f$ & $M S$ & $F$ & $P$-value & F crit \\
Source of Variation & & 7 & 0.07381 & 8.205527 & $2.52 \mathrm{E}-08$ & 2.077558 \\
Between Groups & 0.516667 & 136 & 0.008995 & & & \\
Within Groups & 1.223333 & 143 & & & \\
Total & 1.74 & 143 & & & \\
\hline
\end{tabular}

Week 3:

\begin{tabular}{ccccccc}
\hline ANOVA & \multicolumn{7}{c}{ SS } & $d f$ & $M S$ & $F$ & P-value & F crit \\
Source of Variation & 0.975556 & 7 & 0.139365 & 24.16188 & $3.93 \mathrm{E}-21$ & 2.077558 \\
Between Groups & 0.784444 & 136 & 0.005768 & & & \\
Within Groups & 1.76 & 143 & & & & \\
Total & & & & & & \\
\hline
\end{tabular}

Week 4:

\begin{tabular}{ccccccc}
\hline \multicolumn{7}{c}{ Week 4: } \\
\hline ANOVA & \multicolumn{7}{c}{ SS } & $d f$ & $M S$ & $F$ & $P$-value & F crit \\
Source of Variation & 3.261587 & 6 & 0.543598 & 84.19282 & $1.84 \mathrm{E}-40$ & 2.175659 \\
Between Groups & 0.768333 & 119 & 0.006457 & & & \\
Within Groups & 4.029921 & 125 & & & & \\
Total & & & & & & \\
\hline
\end{tabular}

\subsection{Manageability of the VFH Compared to Traditional Method}

In VHF method, manageability of the farm is quite obvious; the area requires no caretakers considering the number of square meters and the absence of other farming management phases in the traditional method. It requires no preparation which involves the use of farms machinery for plowing, harvesting and the like. There is a little challenge in the use of workforce to manage to harvest, planting and weeding as there are no weeds to grow. A spray of pesticides is no longer needed since the greenhouse prevent foreign pests to enter and attack the VFH. The VHF simplifies farm management and ensures environment-friendly farm operation. Its manageability could be deduced from the shortened preparation, operation and harvesting phases compared to traditional method. It is manageable at its state. 
Table 5. Single factor ANOVA for Phase 1.

\begin{tabular}{rccc}
\hline & $\mathrm{F}$ & $\mathrm{F}_{\text {crit }}$ & P-value \\
\hline Week 1 & 9.4922 & 2.175659 & $1.64 \mathrm{E}-08$ \\
Week 2 & 8.205527 & 2.077558 & $2.52 \mathrm{E}-08$ \\
Week 3 & 24.16188 & 2.077558 & $3.93 \mathrm{E}-21$ \\
Week 4 & 84.19282 & 2.175659 & $1.84 \mathrm{E}-40$ \\
\hline
\end{tabular}

Table 6. Single factor ANOVA for Phase 2.

\begin{tabular}{cccc}
\hline & $\mathrm{F}$ & $\mathrm{F}_{\text {crit }}$ & P-value \\
\hline Week 1 & 26.68622 & 2.175659 & $5.87 \mathrm{E}-20$ \\
Week 2 & 15.49743 & 2.077558 & $8.03 \mathrm{E}-15$ \\
Week 3 & 127.4599 & 2.077558 & $1.56 \mathrm{E}-56$ \\
Week 4 & 21.38035 & 2.175659 & $6.5 \mathrm{E}-17$ \\
\hline
\end{tabular}

Table 7. Single factor ANOVA for Phase 3.

\begin{tabular}{cccc}
\hline & $\mathrm{F}$ & $\mathrm{F}_{\text {crit }}$ & P-value \\
\hline Week 1 & 51.32703 & 2.175659 & $9.51 \mathrm{E}-31$ \\
Week 2 & 77.5361 & 2.077558 & $2.36 \mathrm{E}-44$ \\
Week 3 & 94.95595 & 2.077558 & $3.41 \mathrm{E}-49$ \\
Week 4 & 397.1322 & 2.175659 & $3.37 \mathrm{E}-76$ \\
\hline
\end{tabular}

\subsection{Acceptability of the VHF System to Onion Farmers}

Onion production in Nueva Ecija has declined sharply since 2012 and was not able to pull through unto this time. The use of vertical farming is acceptable to the onion growers considering their past experiences using the traditional method. The acceptability is backed by the belief that 1) change in weather condition or climate change, 2) traditional farming is prone to pest attacks, 3) high cost of farm labor, 4) pesticides, herbicides, and fertilizers. During the interview, the following statements, comments, and opinions of farmers and farmers' cooperative members were taken:

$V F H$ is acceptable because it is resilient to the effects of climate change. "Mahirap na magtanim ngayon kasi sobrang init na, madaming insekto na lumalabas a lupa, yung dahon ng sibuyas nagpa-plastic, medyo mahina na and ani" (translation) "It is difficult to plant onion nowadays because of the climate change, extreme (heat) weather condition made the onion leaves look like plastic and eventually died" (Interviewee two, male)

\section{The VHF is acceptable as to its safe from farm pests}

Farmers consider the method free from farm pests. "young harabas and pinakamatindi, walang itinera sa amin, napakadami nila, di ko alam kung saann nanggaling, malaki ang nawala sa amin" (translation) "among onion pests it is 
harabas that is very difficult to contain they are too many, and we do not know where they come from, it really caused the decline of our income during the last planting season)" (interviewee 3, male)

Farmers consider VHF as safe from flooding. "nung bumaha, wala kami talaga inani, ngayong 2016 ok naman, walang kalamidad na dumating, yun nga lang mahirap mabenta ng magandang presyo kasi madaming imported na dumadating" "inuutang lang naming yung puhunan namin, tapos yung mga kapitalista sila na ang nagdidikta ng presyo ng sibuyas, napipilitan na kami ibenta ng mababa kasi kailangan naming magbayad ng utang" (translation) In 2015, when there was massive flooding, we really did not profit from planting onion, in 2016, we were not affected by calamity but it was very difficult to sell our produce at a good price simply because imported onions flooded the market. We operate on loan proceed only while the capitalists dictate the price of onions in the market and not the growers. It was difficult to sell the product at a reasonable amount (interviewee 3 , male).

"Farmers consider the VHF to be cost-effective in terms of the use fertilizers and pesticides." mahal din ang mga pataba, kailangan din ng pamatay damo at pamatay kulisap, di maiiwasan yun lalo na ngayon, matitibay na ang mga peste, kailangan malakas yung mga gamot para maganda ang ani (translation) the cost of fertilizers, herbicides and festicides are high the solutions must be strong to become effective and to have a good harvests (interviewee 9, woman).

The VHF is acceptable as to decrease in farm labor requirements

"kung mababawasan yung trabaho sa paghahanda ng lupa, tapos sabi mo nga di mahirap magpatubig, ayos yan pero hindi ganon kadali yung pagpapagawa ng taniman (hydro grower) eh mahal eh" (translation) if from labor would be lessened because the VFH system can easily be irrigated compared to traditional farming, it would be better to adopt (interviewee 10, male).

The VHF is acceptable as to Return on Investment (ROI)

"Yung gastos sa hydroponic farming umaabot ng million in one hectare, about 5 to 10 times ng traditional farming, depende sa kung gaano ka-high tech ang gusto mo, pero mataas and yield, almost 10 times din, kasi year-round yung production, kaya in two to three years lang yung payback period, then after that sarili mo na yung kita mo" (translation) the cost of HFV reaches a million pesos$\$ 2000.00$, it is about 5 to 10 times the expense of traditional farming but the yield also is 5 - 10 times that of traditional farming. (interviewee, male).

The VHF is not acceptable because of the big amount required as initial capitalization

"di agad maa-adopt sa onion farming yan kasi mahal, kailangan talaga may government support dyan or may mga capitalist na susugal, at kailangan ng research kung paano yung pag-grow into (onion) sa hydroponic" (translation) "it is not that easy to adopt the technology we need government or capitalist who will gamble their capital to do further research and try the effectiveness of the VHF to onion growing" (interviewee 13, male). 
Majority of the interviewees were excited to adopt the VFH system for onion production. However, the amount of initial capitalization discouraged them to embark on the process. They all believe that the government must provide the subsidy to onion farmers to establish and employ the VHF system.

\section{The Contribution of the VHF System to Onion Production in Nueva Ecija}

The vertical grower design employing hydroponics may be utilized in onion farming in Nueva Ecija for the following reasons: 1) Increased productivity of onions, 2) Year-round crop production, 3) Possibility that can be put up or built anywhere, 4) No weather related crop failures, 5) Onions being free from pesticides and herbicides, 6) Lessening excessive use of fertilizers thus no threat to human and animal health, 7) Requiring less space, so the spare land can be used for fruit bearing trees, which gives additional income to the farmers and helps restore the ecosystem.

The province of Nueva Ecija is not spared from the effects of climate change. It is an agricultural province where the livelihood of the people is dependent on farm produce. As it is an agricultural community, it is dependent on the volume of harvest which in turn is dependent on the quality of weather condition. One way of mitigating the damaging effects of climate change in agriculture may be through new farming methods-the use of controlled-environment agriculture. The use of the vertical hydroponic grower is an appropriate step toward environmental-friendly farming.

The vertical farming or high-rise farming will work. The various vertical farming issues have already been noted. By combining the brains in this world, solutions to its minor imperfections can be found. In the Philippines, it may seem extra ordinary to consider the idea of urban-based agriculture when viable and productive land is available. But with the increase in population, space will eventually be a problem. The arable land is becoming limited, and alternative agricultural practices are necessary. Designing and constructing the vertical farming facility is only part of the challenges toward a sustainable and environment-friendly farming. The readiness and cognition on how to operate the facilities would be a major challenge. More than this, are the challenges of financial and technological viability that ordinary farmers cannot easily adjust to. To make vertical farming a reality, whether small-scale hydroponic farms or flourishing skyscrapers, there is a need for the support of the governments and pioneering organizations' willing to support the farmers and provide them training for technology adoption and financial assistance for the construction of the vertical farms.

Systems research will also be essential for making more rapid progress in diversifying small-scale farms. Many NGOs are active in promoting sustainable low-input agricultural systems in the Philippines and will play an important role in adapting solutions to specific local conditions. Research and development 
from universities should be funded by the government. Through better agricultural governance, and the use of sustainable agricultural technique, we can make significant stride toward food security by the year 2040 .

\section{References}

[1] Alexandratos, N. and Bruinsma, J. (2012) World Agriculture towards 2030/2050: The 2012 Revision. ESA Working Paper No. 12-03. FAO, Rome.

[2] Tilman, D., Cassman, K., Matson, P., Naylor, R. and Polasky, S. (2002). Agricultural Sustainability and Intensive Production Practices. Nature, 418, 671-677. https://doi.org/10.1038/nature01014

[3] Green, R., Cornell, S., Scharlemann, J. and Balmford, A. (2005) Farming and the Fate of Wild Nature. Science, 307, 550-555. https://doi.org/10.1126/science.1106049

[4] Almario, M.F. (2011) Why Philippines Agriculture Lags Behind. Philippine Daily Inquirer.

[5] Bruulsema, T.W., Heffer, P., Welch, M.R., Cakmak, I. and Moran, K. (2012) Fertilizing Crops to Improve Human Health: A Scientific Review. International Fertilizer Industry Association (IFA), Paris.

[6] Gabriel, A.G., Claudio, E.G. and Bolisay, F.A. (2017) Saving Dupinga Watershed in Gabaldon, Nueva Ecija Philippines: Insights from Community Based Forest Management Model. Open Journal of Ecology, 7, 140-157. https://doi.org/10.4236/oje.2017.72011

[7] Philippine Rural Development Project (PRDP) I-PLAN-Department of Agriculture-Value Chain Analysis and Competitiveness Strategy: Bulb Onion.

[8] Despommier, D. (2012) The Vertical Essay. Department of Environmental Health Sciences, Mailman School of Public Health, Columbia University, New York. http://www.verticalfarm.com/?page_id=36

[9] Gabriel, A.G. (2017) Transparency and Accountability in Local Government: Levels of Commitment of Municipal Councillors in Bongabon in the Philippines. Asia Pacific Journal of Public Administration, 39, 217-223. https://doi.org/10.1080/23276665.2017.1368902

[10] Pesticide Facts. RATE/pestfact.html. http://www.chebucto.ns.ca/environment/

[11] Guanlao, A.H. (2011) House Bill No. 720; Urban Agriculture Act of 2013, Sixteenth Congress, First Regular Session.

Bagasina-Cabreara, C. (2011) Urban Agriculture Act of 2011. House of Representatives (Congress), Quezon City,

[12] Gabriel, A.G. and Mangahas, T.L.S. (2017) Indigenous People's Contribution to the Mitigation of Climate Variation, Their Perception, and Organizing Strategy for Sustainable Community Based Forest Resources Management in Caraballo Mountain, Philippines. Open Journal of Ecology, 7, 85-100. https://doi.org/10.4236/oje.2017.72007

[13] Despomier, D. (2010) The Encyclopedia of Earth. Trinity. http://www.eoearth.org/contributor/dickson.despommier

[14] White, J. (2010) Sky-Field: A Vertical Farming Solution for Urban New York. Architecture Theses, Paper 40. http://docs.rwu.edu/archthese/40

[15] Banerjee, C. (2014) Up, Up and Away! The Economics of Vertical Farming. Journal of Agricultural Studies, 2.

[16] Pantuhan, G. 
http://pguims-random-science.blogspot.com/2012/05/hydroponics-concepts-and-m ethods.html

[17] Bradley, P. and Marulanda, C. (2000) Potential of Simplified Hydroponics to Provide Urban Agriculture Income.

[18] Gruber, B. Hydroponic Farming in the Philippines Maximizes Yield at a Minimum Cost. Reuters.

[19] Heiney, A. Farming for the Future. NASA's John F. Kennedy Space Center. https://www.nasa.gov/missions/science/biofarming.html

[20] Jensen, M. Plant Life Sciences, Founder, Controlled Environment Agriculture Center (CEAC). The University of Arizona.

[21] Ohio State University Piketon Research \& Extension Center SWR-2 (1999). 